Trinity University

Digital Commons@ Trinity

Library Faculty Research

Coates Library

$5-2008$

\title{
Communities as Necessity in Information Literacy Development: Challenging the Standards
}

Benjamin R. Harris

Trinity University, bharris@trinity.edu

Follow this and additional works at: https://digitalcommons.trinity.edu/lib_faculty

Part of the Library and Information Science Commons

\section{Repository Citation}

Harris, B.R. (2008). Communities as necessity in information literacy development: Challenging the standards. The Journal of Academic Librarianship, 34(3), 248-255. doi: 10.1016/j.acalib.2008.03.008

This Post-Print is brought to you for free and open access by the Coates Library at Digital Commons @ Trinity. It has been accepted for inclusion in Library Faculty Research by an authorized administrator of Digital Commons @ Trinity. For more information, please contact jcostanz@trinity.edu. 
Communities as Necessity in Information Literacy Development:

Challenging the Standards

Benjamin R. Harris

Assistant Professor

Reference/Instruction Librarian

Elizabeth Huth Coates Library

Trinity University

Benjamin.Harris@Trinity.edu 


\begin{abstract}
$\underline{\text { Abstract }}$
Contemporary standards suggest that information literate activity is a solitary process. As a corrective, research and pedagogical theory related to "learning communities" and "communities of practice" have become valuable sites of inquiry for librarians. The author provides strategies for making community a topic of instruction.
\end{abstract}




\section{$\underline{\text { Introduction }}$}

In academic circles, the term "learning community" holds specific connotations. These prefabricated constructions are often comprised of people with like characteristics, such as a "faculty learning community" or "first-year student learning community." Through the localization of specific components of the greater university, these units are designed to enhance the experiences or opportunities of community members by treating them as "target" populations for whom teaching and learning objectives, methods of communication, and other services are tailored.

While these communities are designed with specific educational aims in mind, it is a fact that all communities---in or outside of the academy---offer opportunities to learn and may require displays of information and knowledge. Physical and virtual constructions of social communities, civic groups, religious organizations, professional associations, as well as communities of work are all learning communities. These "communities of practice" include members that are chosen or self-selected who share specific goals and topics of interest. Information is often created, disseminated, and utilized by members to support the goals of the group. Collaboration and experiential development are necessary activities in communities of practice, and specific or unique uses of language may develop between members.

Recent discussions focused on communities as locations of information literacy learning and development may suggest that this is a new notion among librarians and information professionals. In fact, prior to the information literacy standards published by the Association of College and Research Libraries in 2000, the ACRL's guidelines for bibliographic instruction included outcomes related specifically to communities. This 
removal of community from the standards in favor of a focus on the individual (one who is seemingly able to learn and perform outside of context or environment) is warranted for a number of practical reasons, with difficulties in assessment remaining a primary motivation. However, such a move is reductive in light of the direction being taken by contemporary information literacy instructors, researchers, and practitioners, and should be corrected.

\section{The Loss of "Community" in the Standards}

Librarians entering the profession over the last 10 to 15 years arrived on a wave of advocacy for information literacy instruction. In many ways, information literacy suggested a vital "new" movement of which we were part and parcel. Familiar with the term "bibliographic instruction" as something librarians practiced before information literacy, many of us set BI aside without a second thought. Established professionals who perceived BI as wizened in both theory and practice may have done the same. Information literacy appeared fresh and expansive, characteristics that could drive the creation or revision of instruction programs in academic libraries.

Changes in theory and practice for library instruction had been well underway for more than a decade prior to the publication ACRL's Objectives for Information Literacy Instruction: A Model Statement for Academic Librarians in 2000. The document replaced by the IL standards, The Model Statement of Objectives for Academic Bibliographic Instruction, was published originally in 1988 and again in 1993 in the handbook Read This First: An Owner's Guide to the New Model Statement of Objectives for Academic Bibliographic Instruction. While the title may not be particularly revealing, 
an analysis of this document suggests that it was a key to the growth of information literacy theory and the development of library instruction programs that extended beyond traditional orientation. The 1988 Model Statement also foreshadowed the influence of information literacy with a focus on varying methods of information delivery and retrieval as well as the need for rigorous evaluation of sources by researchers, and was designed to prepare established librarians for changes that would soon appear on the professional horizon. Further, it presented library instruction as an activity with a pedagogical imperative, and recognized that library instruction had a tradition and history, both of which would soon feel the impact of changes in information organization, a more accessible information universe, and increasingly diverse user populations.

In her introduction to the Model Statement, Cerise Oberman writes that the goal of the drafters was to move "away from tool based instruction and toward concept based instruction." Specifically, the "new" Model Statement was a response to its 1979 incarnation, and would include new issues related to library instruction as well as traditional concerns viewed from a contemporary perspective. Objectives and outcomes were revised to show that library instruction was moving away from teaching people how to navigate the card catalog toward asking them to think about "why" information was organized and presented in specific ways. The Model Statement was intended (1) to encourage exploration and critical thinking about what instruction in the library means today, (2) to establish library instruction as a discipline, and (3) to enhance library programs that were already in place. ${ }^{2}$ This third purpose reveals a strategic move on the part of the drafters and the ACRL Instruction Section. Since the Model Statement was not designed for an audience of new librarians, rather to established professionals 
working in instruction programs that would soon feel the pain of necessary change, the document served as a bridge between "traditional" BI philosophies for library instruction and the move toward information literacy theory.

While the BI Model Statement suggested ways to adapt instruction methods to the local environment, the Objectives for Information Literacy Instruction: A Model Statement for Academic Librarians (2001) set a more rigid agenda. It offered objectives that "flesh out and make more specific the Standards, Performance Indicators, and Outcomes of the Competency Standards," a specificity that has led to literal rather than interpretive readings. ${ }^{3}$ One of the obvious reasons for this move was the need for assessment of information literacy learning and development. The construction of more rigid instructional guidelines and learning outcomes would provide the uniformity of design necessary to facilitate standardized assessment methods.

Many of the aims outlined in the BI Model Statement make the transition into the Objectives for Information Literacy Instruction. One exception is the influence of community on literacy development. This consideration is actually the first objective in the BI Model Statement: "The user understands that individuals or groups identify themselves as belonging to specific areas or disciplines"4. The first three indicators for this section of the Model Statement focus on how information relates to the communities that create, disseminate, and store the information. Clearly, understanding the context of information activity is a part of the literacy, one where the information and the researchers involved in its creation and use are not separate entities, and where the use of information occurs in communal situations. 
The discussion of community is almost completely removed from the ILI standards. The only direct mention of community as an influence in information literacy development appears in Standard Four: "The information literate student, individually or as a member of a group, uses information effectively to accomplish a specific purpose."5 The conscious inclusion of "as a member of a group" in the standard (it is not included in the competency standards or performance indicators to follow) does little to suggest that the group vs. individual situation does not completely change the information literacy event in and of itself. It turns the collaborative and social character of the event into an option instead of a requirement of any situation involving communication. Further, placement suggests that it is only in the process of using information that groups of individuals, communities, are involved in the information literacy event.

By adopting a more liberal reading of ILI standards, mention of community may be interpreted in Competency Standard One, Performance Indicator 2: "The information literate student identifies a variety of types of potential sources." ${ }^{\prime 6}$ It is questionable whether or not "sources" here is intended to mean delivery media only. In a wider reading, one could interpret this to mean that "sources" of information could vary beyond the traditional. People, then, could be a source of information, as well as communities; experience is another. Still, as written, the statement depicts information as an object found in the world that is then located and used by the individual. Instead of tool-based instruction with a "resource" as tool, information becomes the tool in this scenario, suggesting that the move from tool-based teaching has been more lateral than progressive. This a definite shift from the BI Model Statement's depiction of research as a community activity involving context as well as content. 


\section{Collaboration and Information Literacy Development}

Information literacy development requires interaction between people and the involvement of people with texts produced by others, making information literacy events intersubjective in character. Wastawy, Uth, and Stewart contend that "The social nature of information seeking means that essentially all information seeking can be seen as collaborative at some level."7 If one views the authors of texts and creators of information as part and parcel of the literacy event, then the individual is never truly working in isolation.

The idea that information literacy requires community, a complex view that extends beyond illusions of the individual learner, requires that one understand the interrelation between community members and their processes related to information. Before we make assumptions about how to assist communities of learning, we may also need to define and navigate the social, political and cultural characteristics of that community. There are two trends on the horizon that suggest directions for dealing with communities and information literacy, while also extending our pedagogical practices and research agenda. One direction for understanding communities, advocated by Annemarie Lloyd, encourages an ethnographic, "outside observer" position as a vantage point to understand the information needs and literacies of specific groups. James Elmborg's recent work on critical information literacy suggests another approach, whereby the librarian takes an activist stance within a community of learners.

Annemarie Lloyd's research, based on observation and research into the practice of firefighters, recognizes that "understanding information literacy in a workplace context requires recognition that information and knowledge are socially produced and 
distributed, and that access to it can be effected by social relationships." ${ }^{8}$ Lloyd's "workplace information literacy" is comprised of "a constellation of skills, practices and processes that depend on relations with experts who afford and mediate the process and thereby, enhance the information practices of the novice." ${ }^{9}$ While situating information literacy development in the realm of landscapes and other natural environments may encourage a deterministic view of information literacy development, Lloyd's aim in using these metaphors is to suggest a big-picture perspective on how information literacy "shows itself" in the activities of the community. Learning outcomes and opportunities for instruction can then be developed to help enhance information literacy learning by focusing on current practice.

In "Critical Information Literacy: Implications for Instructional Practice," James Elmborg argues for a more complicated model of information literacy development that speaks to the social and political concerns of critical literacy theorists Paulo Friere, Henry Giroux, and others. As opposed to the focus on individuals as learners and performers, Elmborg's critical information literacy recognizes how the production, distribution, and uses of information are socio-political processes that require and encourage community involvement. Elmborg contends, "people produce, read, and interpret texts in communities, not in isolation. Communities reach consensus about interpretation, sometimes easily and sometimes contentiously. Literacy cannot be described, therefore, in broad terms as a set of universal skills and abstractable processes. Rather, literacy is in constant flux and embedded in cultural situations, each situation nuanced and different from others." ${ }^{10}$ This move away from the false ideal of the "enlightenment individual" is welcome in library instruction theory and practice. Critical literacy, here blended with 
information literacy, encourages librarians to take an activist stance within learning communities, as members and as educators.

Lloyd and Elmborg offer much to consider with these bold conceptualizations on the position of the librarian within information literacy learning. At the same time, an ethnographic or activist stance will require time, energy, and a local professional culture that encourages — or at least invites_-such changes. The discussion of community and information literacy to follow is meant to situate these options within current research and practice.

\section{Community as the Site of Information Literacy Development}

Learning communities and communities of practice-one constructed and one found-share a number of characteristics. Both groupings are comprised of numerous individuals with similar objectives (personal, professional, and educational in scope) who may have a shared common knowledge and uses of language that are distinctive. Both situations require learning methods of various types, including text-based learning, experiential learning, and often, person-to-person involvement. Learning objectives and strategies for both types of communities may change over time, depending on the needs of the group or a subset of individuals. Multiple methods of communication and information delivery may be utilized to organize community activities and to distribute necessary or even tangential information to members.

Most important to educators is the recognition that learning happens in both types of communities. In developing their theories on community-focused educational experiences," Garrison and Anderson write that a "critical community of learners, from 
an educational perspective, is composed of teachers and students transacting with the specific purpose of facilitating, constructing, and validating understanding, and of developing capabilities that will lead to further learning. Such a community encourages cognitive independence and social interdependence simultaneously." 11 This "community of inquiry" establishes social, intellectual, and instructional components to guide learning community development and efficacy. The processes of creating, locating, evaluating, and using information in various forms does not happen in a vacuum, away from community contexts where meanings and values are in play.

Discussions on community learning and case studies of community-focused programming have thrived in recent years. The shift from tool-based, to problem-based and now collaborative problem-based strategies for teaching information literacy has had a clear influence. Recent research on the habits and desires of "millennial" students is most likely another factor. However, it is advisable not to conflate the trend in collaborative active pedagogy and community learning. As Wastaway, Uth, and Stewart contend in their critical weaving of learning community research and collaborative learning strategies, it is not uncommon to see "learning communities" and "collaborative learning" used as synonyms for one another without recognition of the difference between the social structure of the community and the pedagogical strategy involved in collaborative activity. ${ }^{12}$

In "Faculty-Librarian Collaboration to Achieve Integration of Information Literacy," Lindstrom and Shonrick describe the experiences of librarians working to integrate information literacy learning in a variety of settings. ${ }^{13}$ Citing first-year interest 
groups, linked courses, hybrid learning communities, and cross-curriculum movements as target communities, the authors believe that integrated instruction and instructors will help librarians to "prove their place within the curricular structure of the university." 14

Vickery Kaye Lebbin's analysis of the learning community concept and its application at the University of Hawaii at Manoa finds that the constructed learning community can make long range assessment of information literacy development more feasible. ${ }^{15}$ In addition, development across courses and subject areas encourages the application of information literacy in a variety of teaching and learning contexts. ${ }^{16}$ In an extended analysis of information literacy instruction and its reception in the sciences, Kate Manuel finds that developing knowledge and practices related to specific disciplines and classes may be the best way to refrain from teaching "generic skills" and to encourage the discipline's ownership of information literacy as an instructional focus. ${ }^{17}$

In “The Library and My Learning Community,” Tammy J. Eschedor Voelker describes Kent State's experience in working with a new first year learning community program. ${ }^{18}$ One of the rationales for this move was to encourage experimentation with services and instruction strategies that might not be achievable on a larger scale. Volker cites a proactive staff, support from learning community administrators, and the use of student feedback as valuable components in the integration of information literacy in learning communities.

Recent work by librarians and other information professionals related to communities of practice extends beyond the confines of libraries and schools to focus on "real world" examples of communities in action. The popularity of service learning 
programs in the academy provide connections between "academic" and "real world" locations outside of the traditional academic learning environment, although Lynn C. Westney notes that "contributions that academic librarians have made to this national effort are few and far between." 19

In "Where's the Library in Service Learning?: Models for Engaged Library Instruction," John S. Riddle offers a cogent line of reasoning for the service learning/information literacy connection. Riddle's three models of information literacy instruction (learning process model, course objectives mode, subject content model) all serve as strategies for participating in a service learning community. This participation not only enhances the experience of the learner, but encourages "more rigorous engagement with faculty and their pedagogy, an engagement with broad community (campus and non-campus) social and education issues," as well as an opportunity to examine "its own role in the higher education curriculum to determine its degree of relevance/irrelevance." ${ }^{20}$

Opportunities for librarian involvement in student communities have been transformed by social networking programs and virtual community settings. When the standards were published, the popularity of virtual communities and their potential uses for delivering instruction could not have been predicted. From course software focused on student learning communities to social Web sites targeting the entire campus and beyond, librarians are developing methods for offering guidance and instruction online with the same ease of access afforded many of the library's digital resources. 
Costello, Lenholdt, and Stryker offered an early case study of using the learning management system Blackboard to reach students in specific courses and local academic communities at Stetson University. With a focus on adapting library instruction to the learning styles of the contemporary student, the authors found that providing assistance at the closest "point-of-need" meant participating in their class community's online locale. ${ }^{21}$ In her suggestions for exploiting recent advances in Blackboard technology to deliver information related to library resources and services, Pamela Alexondra Jackson from San Diego State advocates a number of outreach initiatives that include the creation of “student homerooms" by librarians. ${ }^{22}$ Ultimately, when students have access to most of the library's resources through the use of computers, both in and outside of the library, offering instruction in a similar manner speaks to the expectations that have already been established by the ease of accessing sources online.

The provision of community-specific virtual instruction has received less attention than librarians' forays into informal and untamed online social networking sites. In her review of libraries using MySpace to reach local student communities, Beth Evans suggests that the wealth of student information available in online profiles allows librarians to better understand their user populations. ${ }^{23}$ Such applications of social networking technologies speaks to Lloyd's aesthetic of ethnographic research to better understand the information literacy needs of specific groups.

In their experiments to involve the library in student social activity using Facebook, Miller and Jensen contend that creating library "groups" for users to join is not an effective use of the technology. ${ }^{24}$ Instead, the authors suggest that librarians involve themselves in the Facebook habit of "friending" other participants and encouraging them 
to "friend" the library in return. Additional suggestions focus on using the "culture" of the resource to engage student interest and to market the library's services and resources. Other authors continue to venture into uncharted territory at the bleeding edge of Web 2.0. From experiments in the virtual reality space Second Life, to social bookmarking tools used to engage students in learning, and predictions on connections between the social networking and semantic Webs, the reach of librarians seems endless. ${ }^{25}$ While one can argue that this type of virtual presence does not necessarily indicate the occurrence of learning experiences that extend beyond immediate and convenient online access to the library, meeting students "where they are" in the physical/virtual sense may facilitate better instruction practices and programs that have the capacity to reach a wider student audience. However, these examples may not be the professional "norm." According to Charnigo and Barnett-Ellis's survey of librarians across the country, many librarians are not using social software to reach students. ${ }^{26}$ The primary reason for this seems to be a distinction between "recreational" and "academic" online activity.

A possible resolution for this type of concern may appear in correlations between "academic" and "professional" spheres. Educators in medical and law libraries have naturally been far more focused in understanding and assisting student communities as future communities of practice. The use of technologies and information resources in other disciplines has begun to create opportunities for this type of connection elsewhere. For example, Jeremy Donald contends that geographic information systems (GIS) communities should be considered "communities of practice" for whom information literacy instruction is necessary and has offered specific suggestions for meeting 
information literacy competency objectives with these groups. ${ }^{27}$ His suggestions for teaching GIS users in and outside of the classroom makes a strong argument for applying information literacy competency objectives to virtual communities that blend the academic with the professional. Advocates of lifelong learning must cultivate more opportunities for this type of cross-community instruction, and develop assessment measures to determine effectiveness.

\section{Making Community the Content}

While these and other examples for considering community when planning and providing learning opportunities are extremely valuable to instructors, rarely is the topic of "community" an issue in the learning outcomes. One reason for this, as with many "optional" topics, is a lack of time or available resources. Stand-alone classes could design curricula in which community is a focus of the course content with some ease. One-shot and workshop sessions may have greater difficulty. Making connections between information literate activity and academic, social, and professional situations will increase the relevance of instruction. In addition, issues related to the needs, desires, and values of communities may help to address certain information literacy competency outcomes that are often neglected.

The following categories suggest discussion and activities to help elucidate issues related to communities, information, and learning as a topic in the classroom. While these are offered in a suggested sequence, instructors may choose one category for focus, or limit the requirements of each sequence to complete an activity in a reasonable time 
frame. Brief outlines of activities designed to blend with other class session topics and activities are included in the Appendix.

\section{Defining Communities}

While broads questions such as "what is a community?" may be useful in some teaching sessions, a more efficient way to handle the task of definition would be to ask, "what are your communities?" The answer will suggest a personalized concept of community, while lending itself to discussion on standard definitions. This provides students with a personal stake and the discussion with greater relevance.

In most of these community situations, participants are associated with one another by choice or necessity, and the means of membership will most likely have an influence on the activities of a community. One may even become a member of a community by default without receiving the benefit of choice. Napierville, a suburb of Chicago, is a physical community, as is the Introduction to Humanities class at Stanford University. It is not a requirement that everyone in Illinois lives in Naperville, but it is required that all first-year students at Stanford take an introductory humanities course. An individual's immediate family and extended family could be considered separate communities, or may be further divided based on lineage. In the case of the family community, one's choices relate not to membership but to the personal investment and participation in that community's activities.

Communities may construct a virtual presence, and exist as physical AND virtual communities. The Applebee's restaurant on West Emerald in Boise is a physical community that acts in concert with a virtual community at Applebees.com. The 
Paintball Network on MySpace.com, Mensa, and the University of Tennessee's alumni group in Charlotte, North Carolina are all communities. It is often surprising for students (and others) to recognize the breadth of their community involvement, an involvement that has become even greater due to diverse electronic communications strategies and their proliferation.

Strategies for communication adopted by communities may also help to characterize their goals, activities, and member populations. Lenning and Ebbers describe three specific types of interaction within communities: physical, virtual (synchronous), and correspondent (asynchronous). ${ }^{28}$ The design of these communities and methods of interaction may hinge on the group's characteristics. For example, a learning community of distance-education students or working professionals in graduate programs may benefit from specific kinds of interaction that would be difficult via other means.

Introductions to new or diverse communities and the way these communities are similar or vastly different from others may also help to expand students' perspectives on community. In addition, increasing one's knowledge about other groups will help students to define their own communities more closely as a point of comparison. Critical thinking that seeks to compare community definitions and strategies of connectivity may also depict interconnectivity between groups, and the ways communities negotiate with one another.

\section{The Location of Learning in Communities}

Activities associated with community-based learning, where such learning is either required or desired by members of a community, may be explicit components of 
community participation. For example, academic communities tend to focus on specific learning objectives that are presented in very conscious ways. A work community may differ, since the higher objective may be to sell items or to provide a service. A salesperson in a clothing store may see the provision and sales of goods as his or her primary objective. The learning process involved in providing and selling goods may not be primary, since one can learn about the goods and still not sell them. Social communities will not often "require" the acquisition of new skills or knowledge; development in these situations may be based primary on the community member's personal desires. In communities outside of the structure of academia, learning goals and processes often become veiled amidst other tasks that are designed to achieve the primary goal of that specific community.

Lloyd located three sites of knowledge where learning was either necessary or desirable:

- Social sites of knowledge: experiential information (relating to the accumulated knowledge gained through the experiences of others) and affective information (such as group values and attitudes towards work) that relates to the workplace and workplace performance. Social sites also reinforce textual information valued by the community of practice.

- Physical sites of knowledge which are constituted through the actions of the body in rehearsal and practice.

- Textual sites, which are constituted through access to information through the formal statements of work and practice. This information remains abstract and predictable until experienced by the practitioner. ${ }^{29}$ 
Without question, these sites of knowledge are not mutually exclusive. As Lloyd defines social sites of knowledge, she is careful to connect textual learning with social activity. While members of a community may favor a specific type of learning methodology, and while the community construction itself may demand a certain hierarchy of learning experiences, these sites of knowledge do not take away from another but overlap and build beyond a single type of learning activity.

Ultimately, these categories expand our thinking about where learning happens. The image of the individual in the library poring over stacks of open books is a common trope of learning, as is the classroom of students with a teacher as guide. Considering social and physical sites of knowledge acquisition, information use, and sharing through various means of delivery allows for a broader view of communities-based learning.

\section{Information Literacy in Communities}

Once knowledge requirements and learning opportunities have been determined for specific communities, the information literacy objectives of that community should become clear. What kinds of information does the community need? Does the community create and distribute information? What is the purpose or intended goals after information has been created and distributed? How is the information delivered? Does delivery method have an impact on how it is used and stored? How does the "literacy" involved in community participation involve information literacy?

Note that the final question does not ask "if" information literacy is involved, but "how" it is involved. Since communication between members defines a community, collaboration occurs regardless of delivery media. When communication ends, when no 
information changes hands, the community dissolves. However, one should not make the assumption that the lack of written contact suggests that communication has ended. New, old, reorganized and revised information may be contained in a vocal exchange, or the result of an experiment or group endeavor, in addition to traditional written forms. As Annemarie Lloyd writes,

It requires a broader and more complicated information relationship that necessitates engagement not only with textual sources but also with physical and social modalities. Understanding information literacy in a workplace context requires recognition that information and knowledge are socially produced and distributed, and that access to it can be affected by social relationships. This requires learners to reorient themselves away from individualized learning towards the information and sites of knowledge valued by the community of practice. ${ }^{30}$

The issue of "value" as perceived by communities is vital for understanding information literacy development beyond formal school and academic instruction. Our instruction sessions may encourage students to recognize the difference between popular and scholarly resources, and to develop capacities that allow them to cope when faced with “print-only" assignment requirements and similar efforts, but do we emphasize how these definitions and distinctions are the concern of a specific type of community in which one may participate? And that the values and expectations of other communities may differ? Might we ask them to think critically about the values of the communities in which they participate, specifically those values and expectations related to communication, information creation, delivery, and reception? 
The ACRL's Information Literacy Competency Standard 3 includes performance indicators directly related to the issue of value: "The information literate student determines whether the new knowledge has an impact on the individual's value system and takes steps to reconcile the difference" ${ }^{31}$ Located at the "dead center" of the standards, it is an easy consideration to overlook and upon a review the literature, it is likely that this tendency has extended to professional practice as well. How many may want to overlook it, or designate the responsibility elsewhere?

Part of the challenge in dealing with the issue of value may be a duo of unhelpful learning outcomes. The task of investigating different viewpoints in the literature has little to do with one's value system, and the incorporation or rejection of these perspectives seems a fairly flippant means of "reconciliation." What is absent here is explication or even the whisper of recognition that value systems are created in and by communities, and that the acts of valuing new knowledge or reconciling issues related to new knowledge may be determined by an individual who is acting in concert with many other individuals in various communities.

Academic librarians teaching students about research, reading, and writing in the university and how these activities are constructed and guided by the values of the academy may also wish to make connections with students' personal, professional and educational value systems. The ability to recognize and comprehend the values of communities, and apply those values in the creation, transmission, or receipt of information, is a core activity in the development of "common knowledge" between community members. Setting the stages of lifelong learning and information literacy 
development requires populating the scene with the individuals and communities that will guide, inspire, and help construct the learning environment and experiences ahead.

\section{$\underline{\text { Reconsidering Objectives }}$}

The Information Literacy Competency Objectives for Higher Education has been and will continue to be extremely influential to library instruction programs and the students and others who benefit. The desire to keep these goals and objectives lean and precise make teaching and learning about information literacy development a more efficient, and hopefully assessable, project. We must remember that the deployment of these standards, objectives and outcomes designed for the assessment of information literacy development, are not the core of this learning but merely indicators of the new skills and knowledge in applied situations.

Our professional literature and other forms of professional communications encourage us to build upon and improve upon these objectives as we see changes in our local goals, in students, technologies, and a flourishing information universe. While the current standards may set aside explicit outcomes focused on communities as the primary location of information literacy learning and practice, information literacy educators have not followed suit. Without question, future competency objectives, model statement, or standards will give adequate attention to the ways that communities remain necessary to information literacy development. 
${ }^{1}$ Cerise Oberman, "Introduction," in Read This First: An Owner's Guide to the New Model Statement of Objectives for Academic Bibliographic Instruction, edited by Caroly Dusenbury (Chicago: Bibliographic Instruction Section, Association of College and Research Libraries, 1991): pp. 1-4.

${ }^{2}$ Association of College and Research Libraries, Bibliographic Instruction Section, "Model Statement of Objectives for Academic Bibliographic Instruction," in Read This First: An Owner's Guide to the New Model Statement of Objectives for Academic Bibliographic Instruction, edited by Carolyn Dusenbury (Chicago: Bibliographic Instruction Section, Association of College and Research Libraries, 1991): pp. 5-15.

${ }^{3}$ Association of College and Research Libraries, Information Literacy Competency

Standards for Higher Education (Chicago: American Library Association, 2000).

${ }^{4}$ ACRL, "Model Statement," p. 8.

${ }^{5}$ ACRL, Information Literacy, p. 13.

${ }^{6}$ Ibid., p. 8.

${ }^{7}$ Sohair F. Wastawy, Charles W. Uth, and Christopher Stewart, "Learning Communities: An Investigative Study into Their Impact on Library Services," Science and Technology Libraries 24 (2004): 327-374.

${ }^{8}$ Annemaree Lloyd, "Information Literacy Landscapes: An Emerging Picture," Journal of Documentation 62 (2006): 570-583.

${ }^{9}$ Ibid., p. 576.

${ }^{10}$ James Elmborg, "Critical Information Literacy: Implications for Instructional Practice," Journal of Academic Leadership 32 (2006): 192-199.

${ }^{11}$ D.R. Garrison and Terry Anderson, E-Learning in the $21^{\text {st }}$ Century: A Framework for 
Theory and Practice (London: Routledge): p. 23.

${ }^{12}$ Wastawy, Uth, and Stewart, "Learning Communities" p. 333.

${ }^{13}$ Joyce Lindstrom and Diana D. Shonrick, "Faculty-Librarian Collaboration to Achieve Integration of Information Literacy," Reference and User Services Quarterly 46, no. 1 (2006): 18-23.

${ }^{14}$ Ibid., p. 22.

${ }^{15}$ Vickery Kaye Lebbin, "Students Perceptions on the Long-Range Value of Information Literacy Instruction Through a Learning Community," Research Strategies 20 (2006): 204-218.

16 Ibid., p. 206.

${ }^{17}$ Kate Manuel, "Generic and Discipline-Specific Information Literacy Competencies: The Case of the Sciences," Science and Technology Libraries 24 (2004): 279-308.

18 Tammy J. Eschedor Voelker, “The Library and My Learning Community: First Year Students’ Impressions of Library Services," Reference and User Services Quarterly 46, no. 2 (2006): 72-80.

${ }^{19}$ Lynn C. Westney, "Conspicuous by Their Absence: Academic Librarians in the Engaged University," Reference and User Services Quarterly 45 (Spring 2006): 200203.

${ }^{20}$ John S. Riddle, "Where's the Library in Service Learning?: Models for Engaged Library Instruction,” Journal of Academic Librarianship 29 (March 2003): 71-81.

${ }^{21}$ Barbara Costello, Robert Lenholt, and Judson Stryker, "Using Blackboard in Library Instruction: Addressing the Learning Styles of Generations X and Y," Journal of Academic Librarianship 30, no. 6 (2004): 452-460. 
${ }^{22}$ Pamela Alexondra Jackson, “Integrating Information Literacy Into Blackboard:

Building Campus Partnerships for Successful Student Learning," Journal of Academic Librarianship 33, no. 4 (2007): 454-461.

${ }^{23}$ Beth Evans, "Your Space or MySpace," Library Journal 131 (2006): 8-12.

${ }^{24}$ Sarah Elizabeth Miller and Lauren A. Jensen, "Connecting and Communicating with

Students on Facebook," Computers in Libraries 27, no. 8 (2007): 18-22.

${ }^{25}$ For examples see Esther Grassian, Rhonda B. Truman, and Patrice Clemson, "Stumbling, Bumbling, Teleporting, and Flying...Librarian Avatars in Second Life," Reference Services Review 35, no. 1 (2007): 84-89; Melissa L. Rehtlefsen, “Tags Help Make Libraries Delicio.us," Library Journal 132, no. 15 (2007): 26-28; Maged N. Kamel Boulos and Steve Wheeler, “The Emerging Web 2.0 Social Software: An Enabling Suite of Sociable Technologies in Health and Health Care Education," Health Information and Libraries Journal 24, no. 1 (2007): 2-23.

${ }^{26}$ Laurie Charnigo and Paula Barnett-Ellis, "Checking Out Facebook.com: The Impact of a Digital Trend on Academic Libraries," Information Technology and Libraries 26, no. 1 (2007): 23-34.

${ }^{27}$ Jeremy Donald, "GIS as a Web 2.0 Education Tool," ESRI Education User Conference (2007). Available: http://gis.esri.com/library/userconf/educ07/educ/papers/pap_1846.pdf (September 14, 2007).

${ }^{28}$ Oscar T. Lenning and Larry H. Ebbers, The Powerful Potential of Learning Communities: Improving Education for the Future, ASHE-ERIC Higher Education Report Volume 26, Number 6 (Washington, D.C.: ERIC Clearinghouse on Higher Education, Association for the Study of Higher Education, George Washington 
University, 1998), p. 11-12.

${ }^{29}$ Anne Lloyd, "No Man (Or Woman) is an Island: Information Literacy, Affordances and Communities of Practice," Australian Library Journal 54, no. 3 (2005). Available: http://www.alia.org.au/publishing/alj/54.3/full.text/lloyd.htm (July 5, 2007).

${ }^{30}$ Lloyd, "Information Literacy," p. 574.

${ }^{31}$ ACRL, Information Literacy, p. 11-12. 
Appendix: Practical Strategies for Making Community Course Content

\section{Defining Communities}

\begin{tabular}{|c|c|}
\hline Objectives & Activities \\
\hline $\begin{array}{l}\text { Students will be able to define } \\
\text { "community" in formal terms and interpret } \\
\text { this definition of the term via current } \\
\text { usage. }\end{array}$ & $\begin{array}{l}\text { Locate a definition of community using a } \\
\text { standard dictionary or reference source. } \\
\text { Then, using an (assigned) online search } \\
\text { engine or library database, do a keyword } \\
\text { search using the term "community." } \\
\text { Browse } 5 \text { to } 10 \text { results. Based on this } \\
\text { review, how is the term "community" } \\
\text { being used as a descriptive term? Is } \\
\text { learning a conscious objective of the } \\
\text { community? }\end{array}$ \\
\hline $\begin{array}{l}\text { Students should be able to recognize the } \\
\text { characteristics of community categories as } \\
\text { well as those of specific communities. }\end{array}$ & $\begin{array}{l}\text { Select a category of community (familial, } \\
\text { social, professional/trade, } \\
\text { scholarly/academic, creative) and define it } \\
\text { as specifically as possible. Then, define a } \\
\text { specific community located within that } \\
\text { category. Specifically, what are the } \\
\text { similarities and differences between how } \\
\text { learning occurs in these different groups? }\end{array}$ \\
\hline $\begin{array}{l}\text { Students should be able to locate numerous } \\
\text { examples of communities in which they are } \\
\text { involved. }\end{array}$ & $\begin{array}{l}\text { Ask students to list the communities in } \\
\text { which they participate. Then, ask students } \\
\text { to determine if membership was chosen or } \\
\text { necessary. What are the differences } \\
\text { between communities in which one } \\
\text { chooses to participate and those that are } \\
\text { required? How does this relate to learning } \\
\text { in the community? }\end{array}$ \\
\hline
\end{tabular}

The Location of Learning in Communities

\begin{tabular}{|c|c|}
\hline Objectives & Activities \\
\hline $\begin{array}{l}\text { Students should be able to determine the } \\
\text { learning needs of members in communities. }\end{array}$ & $\begin{array}{l}\text { Ask students to determine the learning } \\
\text { needs of individuals in one of the } \\
\text { communities in which they participate. } \\
\text { Determine if "members" and "transient } \\
\text { participants" require the same learning } \\
\text { experiences. }\end{array}$ \\
\hline
\end{tabular}




\begin{tabular}{|l|l|}
\hline $\begin{array}{l}\text { Students should be able to determine if } \\
\text { learning needs are ongoing or resolved by } \\
\text { instruction/information transfer. }\end{array}$ & $\begin{array}{l}\text { Ask students to categorize learning needs } \\
\text { as finite or continual. Why is this } \\
\text { characteristic important to members? To } \\
\text { possible members? }\end{array}$ \\
\hline $\begin{array}{l}\text { Students should be able to diagnose the } \\
\text { sites of knowledge valued by specific } \\
\text { communities. }\end{array}$ & $\begin{array}{l}\text { Offer a brief explanation of Lloyd's three } \\
\text { sites of knowledge. Ask student to } \\
\text { determine a primary, secondary, and } \\
\text { tertiary site of knowledge for the } \\
\text { community. How are these sites of } \\
\text { knowledge interrelated? }\end{array}$ \\
\hline
\end{tabular}

\section{Information Literacy in Communities}

\begin{tabular}{|l|l|}
\hline \multicolumn{2}{|c|}{ Objectives } \\
\begin{tabular}{|l} 
Students will be able to diagnose the \\
information needs and possible sources of \\
information for a specific community.
\end{tabular} & $\begin{array}{l}\text { Students will select a specific community } \\
\text { in which they are members. Determine } \\
\text { what kinds of information are used by the } \\
\text { group and where the information might be } \\
\text { located. Offer examples. }\end{array}$ \\
\hline $\begin{array}{l}\text { Students will be able to diagnose possible } \\
\text { information needs and likely sources of } \\
\text { information for an academic community. }\end{array}$ & $\begin{array}{l}\text { Students be assigned (or may select) a } \\
\text { specific academic discipline (possibly, one } \\
\text { in which they are majors or are considering } \\
\text { as a major area of study). Determine the } \\
\text { kinds of information valued by the } \\
\text { community and where they might locate } \\
\text { the information. }\end{array}$ \\
\hline $\begin{array}{l}\text { Students will be able to distinguish } \\
\text { likenesses and differences between the } \\
\text { information needs and possible sources of } \\
\text { resolution for different types of } \\
\text { communities. }\end{array}$ & $\begin{array}{l}\text { Students will select a professional } \\
\text { organization and determine the } \\
\text { community's primary strategies for } \\
\text { meeting the information needs of members. } \\
\text { Determine how a profession is similar or } \\
\text { different when compared to an academic } \\
\text { discipline. }\end{array}$ \\
\hline
\end{tabular}

